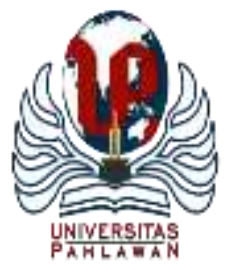

Edukatif : Jurnal Ilmu Pendidikan Volume 4 Nomor 1 Tahun 2022 Halm 1182 - 1192

EDUKATIF: JURNAL ILMU PENDIDIKAN

Research \& Learning in Education

https://edukatif.org/index.php/edukatif/index

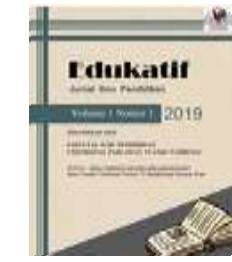

\title{
Pengaruh Pembelajaran Microteaching, Praktik Lapangan Persekolahan, dan Efikasi Diri Terhadap Minat Menjadi Guru SMK Akuntansi
}

\author{
Atika Alifia $^{1 凶}$, Han Tantri Hardini ${ }^{2}$ \\ Universitas Negeri Surabaya, Indonesia ${ }^{1,2}$ \\ E-mail : atika.18008@mhs.unesa.ac.id ${ }^{1},{\underline{\text { hanhardini@ } \text { unesa.ac.id }^{2}}}^{2}$
}

\begin{abstract}
Abstrak
Tujuan peneliti melakukan penelitian yaitu untuk mengetahui pengaruh secara parsial dan juga simultan pada variabel bebas pembelajaran microteaching, PLP II, dan efikasi diri terhadap variabel terikat minat menjadi guru SMK akuntansi. Metode penelitian menggunakan metode penelitian kuantitatif dengan populasi mahasiswa Pendidikan Akuntansi Universitas Negeri Surabaya angkatan 2018 yang melakukan praktik mengajar (PLP II dan Kampus Mengajar) sejumlah 55 mahasiswa dengan menggunakan sampel populasi atau sampel jenuh. Kuesioner digunakan peneliti untuk teknik pengumpulan data sedangkan metode analisis data yang digunakan peneliti yaitu analisis regresi linier berganda. Aplikasi yang digunakan peneliti dalam menganalisis penelitian ini adalah SPSS versi 25. Penelitian memiliki hasil yaitu menunjukan bahwa minat menjadi guru SMK akuntansi secara simultan dipengaruhi oleh pembelajaran microteaching, PLP II dan efikasi diri. Namun secara parsial, pembelajaran microteaching tidak berpengaruh signifikan terhadap minat menjadi guru SMK akuntansi, PLP II tidak berpengaruh secara signifikan terhadap minat menjadi guru SMK akuntansi, efikasi diri berpengaruh signifikan terhadap minat menjadi guru SMK akuntansi.
\end{abstract}

Kata Kunci: Microteaching, PLP II, Efikasi Diri, Minat.

\section{Abstract}

The purpose of the research is to determine the effect of partially and simultaneously on the independent variables of microteaching learning, PLP II, and self-efficacy on the dependent variable of interest in becoming an accounting vocational teacher. This research method uses quantitative research methods with a population of students of Accounting Education, State University of Surabaya class 2018 who practice teaching (PLP II and Campus Teaching) of 55 students using a population sample or saturated sample. Questionnaires were used by researchers for data collection techniques, while the data analysis method used by researchers was multiple linear regression analysis. The application used by the researcher in analyzing this research was SPSS version 25. The results showed that interest in becoming an accounting vocational teacher was simultaneously influenced by microteaching, PLP II, and self-efficacy learning. But partially, microteaching learning has no significant effect on interest in becoming an accounting vocational school teacher, PLP II does not significantly affect interest in becoming an accounting vocational school teacher, self-efficacy has a significant effect on interest in becoming an accounting vocational school teacher.

Keywords: Microteaching, PLP II, Self-Efficacy, Interest.

Copyright (c) 2022 Atika Alifia, Han Tantri Hardini

$\triangle$ Corresponding author:

Email : atika.18008@mhs.unesa.ac.id

DOI : https://doi.org/10.31004/edukatif.v4i1.2075

ISSN 2656-8063 (Media Cetak)

ISSN 2656-8071 (Media Online)

Edukatif : Jurnal Ilmu Pendidikan Vol 4 No 1 Tahun 2022 p-ISSN 2656-8063 e-ISSN 2656-8071 
1183 Pengaruh Pembelajaran Microteaching, Praktik Lapangan Persekolahan, dan Efikasi Diri Terhadap Minat Menjadi Guru SMK Akuntansi - Atika Alifia, Han Tantri Hardini

DOI: https://doi.org/10.31004/edukatif.v4i1.2075

\section{PENDAHULUAN}

Pendidikan merupakan usaha dari seorang individu atau kelompok untuk mematangkan pemikiran manusia dengan memberikan bimbingan pelajaran dan pelatihan (KBBI, 2021). Pendidikan mampu menyelesaikan permasalahan-permasalahan yang nantinya dihadapi oleh generasi muda. Pemerintah Republik Indonesia telah berupaya dengan program-program yang dilaksanakan untuk meningkatkan pendidikan di Indonesia. Pendidikan tentunya tak luput dari peran seorang pendidik atau guru. Guru adalah komponen utama dalam pendidikan. Guru merupakan tenaga pendidik yang dipandang memiliki kedudukan strategis untuk pembangunan nasional (UU NO 14, 2005). Guru merupakan seseorang yang sangat penting untuk menciptakan muda-mudi yang berbobot atau bermutu melalui tugas pendidik sebagai seorang guru atau pendidik. Tugas utama seorang guru sebagai tenaga pendidik yaitu membimbing, mendidik, melatih, mengajar, memberi nilai, dan mengevaluasi peserta didik dalam seluruh jenjang pendidikan dari yang ada di jenjang pendidikan dasar ataupun jenjang pendidikan menengah. Seorang guru atau pendidik yang berkualitas memiliki peran penting untuk mewujudkan sumber daya manusia yang bermutu atau berkualitas.

Memilih menjadi seorang guru atau pendidik, bukan suatu hal yang mudah, Dikarenakan guru atau pendidik tidak hanya memberikan materi di kelas akan tetapi juga memberikan bimbing dan membentuk berbagai macam karakter siswa (Aini, 2018). Mahasiswa yang memilih kuliah dibidang pendidikan tentunya diajarkan tentang tugas dan tanggung jawab menjadi seorang guru dan diimplementasikan dalam praktik mengajar berupa microteaching dan PLP II.

Yuniasari \& Djazari ( 2017) mendefinisikan minat menjadi guru yaitu usaha seseorang untuk menjadi seorang guru yang professional dengan cara menempuh pendidikan yang sesuai dengan persyaratan menjadi guru. Lulusan S1 Pendidikan Akuntansi Fakultas Ekonomika dan Bisnis Unesa dicetak menjadi seorang guru SMK swasta atau negeri sehingga diharapkan mahasiswa S1 Pendidikan Akuntansi Unesa memiliki minat menjadi guru. Berikut adalah hasil tracer mahasiswa lulusan program studi pendidikan akuntansi terkait dengan minat pekerjaan antara tahun 2018-2020 sebagai berikut:

\section{Tabel 1}

Tracer studi Pendidikan Akuntansi 2018-2020

\begin{tabular}{ccc}
\hline Sektor & Banyak & Persentase \\
\hline Pendidikan & 58 & $30 \%$ \\
\hline Wirausaha & 2 & $1 \%$ \\
\hline BUMN & 10 & $5 \%$ \\
\hline Swasta & 66 & $35 \%$ \\
\hline Lainnya & 56 & $29 \%$ \\
\hline Jumlah & 192 & $100 \%$
\end{tabular}

Sumber data: Hasil tracer study Prodi Pendidikan Akuntansi tahun 2020

Berdasarkan tabel hasil tracer study Prodi Pendidikan Akuntansi 2018-2020 dapat dilihat bahwa mahasiswa yang memilih sesuai dengan pendidikannya yaitu menjadi seorang pendidik hanya $30 \%$ Sedangkan sisanya yaitu $70 \%$ memilih untuk tidak menjadi pendidik atau memilih profesi lain. Selain hasil tracer study peneliti juga melakukan wawancara kepada beberapa mahasiswa S1 Pendidikan Akuntansi Unesa. Wawancara pertama dilakukan kepada mahasiswa A yaitu mahasiswa yang menyebutkan bahwa subyek A memiliki minat menjadi guru dari awal memilih pendidikan akuntansi sampai semester 7 alasan subyek A berminat menjadi guru dikarenakan subyek A memiliki keinginan dari kecil sampai sekarang untuk menjadi seorang guru. Wawancara selanjutnya dilakukan kepada subyek B yang menyebutkan bahwa memiliki minat menjadi guru setelah mempelajari dan mempraktikkan bagaimana menjadi guru selain itu subyek B juga mengatakan bahwa dengan adanya pembelajaran mengenai keguruan subyek B mulai tertarik dan berkeinginan menjadi guru. Wawancara selanjutnya dilakukan terhadap Subyek C yang menjelaskan bahwa subyek C berkeinginan 
1184 Pengaruh Pembelajaran Microteaching, Praktik Lapangan Persekolahan, dan Efikasi Diri Terhadap Minat Menjadi Guru SMK Akuntansi - Atika Alifia, Han Tantri Hardini

DOI: https://doi.org/10.31004/edukatif.v4i1.2075

menjadi guru dikarenakan subyek $\mathrm{C}$ merasa mampu mengerjakan tugas sebagai seorang guru saat melaksanakan PLP II. Wawancara selanjutnya diberikan kepada subyek D yang menjelaskan bahwa subyek D memiliki minat menjadi guru dikarenakan subyek D memiliki pengalaman mengajar di instansi sekolahan dan menyukai kegiatan mengajar di kelas tersebut. Wawancara selanjutnya diberikan kepada subyek E yang menjelaskan bahwa subyek E tidak memiliki minat menjadi guru dikarenakan subyek E menganggap pekerjaan guru memiliki tanggung jawab besar dan beban moral. Wawancara selanjutnya dilakukan terhadap subyek F yang menyatakan bahwa Subyek F ingin menjadi guru dikarenakan Subyek F merasa senang dengan pengalaman mengajar yang diberikan di PLP II dan juga pengalaman-pengalaman kependidikan yang pernah dialami, Wawancara terakhir dilakukan terhadap subyek $G$ yang menyatakan bahwa Subyek $G$ tidak ingin menjadi guru melainkan berkeinginan menjadi salah satu pegawai perusahaan di SCBD dikarenakan gaji guru relative kecil. Dari studi pendahuluan yang dilakukan peneliti yaitu berupa hasil tracer dan wawancara dapat disimpulkan mahasiswa yang berminat menjadi guru sangat sedikit dan tentunya terdapat beberapa faktor yang memiliki pengaruh pada minat menjadi guru.

Menurut Nugroho dkk (2016) faktor yang memiliki pengaruh pada minat menjadi guru dibagi menjadi 2 yaitu faktor eksternal atau dari luar dan internal atau dari dalam individu. Faktor internal terdiri atas faktor kepribadian dan sikap seperti nilai sosial yang tinggi, perhatian terhadap mutu dari pendidikan, mempunyai tantangan, mempunyai manfaat bagi orang lain, memiliki cita-cita atau keinginan menjadi seorang guru, mengikuti kegiatan seminar atau kegiatan yang memberikan pengetahuan tentang guru, memiliki atau mempunyai pengalaman mengajar. Faktor eksternal atau faktor dari luar dari minat menjadi guru terdiri dari faktor keluarga dan faktor teman.

Program studi Pendidikan Akuntansi Unesa memiliki tujuan untuk menciptakan guru-guru yang bermutu. Dengan tujuan itu maka Pendidikan Akuntansi Unesa menyusun kurikulum terkait perkuliahan microteaching dan PLP II untuk mahasiswa Pendidikan Akuntansi Unesa. Pembelajaran microteaching adalah salah satu faktor internal dari minat menjadi guru yaitu faktor internal memiliki pengalaman mengajar. Microteaching adalah pembelajaran secara teori atau praktik bagaimana cara mengajar dengan benar sesuai kurikulum yang berlaku di Indonesia (Karyantini \& Rochmawati, 2021)

Selain microteaching mahasiswa juga melaksanakan kegiatan PLP II (Pengenalan Lapangan Persekolahan 2). Tujuan dari PLP II adalah untuk menambah pengalaman mengajar secara langsung. Kegiatan PLP II pada saat pandemic Covid-19, pembelajaran luring di SMK dilaksanakan sebesar 25\% dari kapasitas, sedangkan $75 \%$ dilakukan secara daring dengan menggunakan media pembelajaran elektronik contohnnya Zoom, google meet, google classroom dan sebagainya.

Faktor internal yang diduga mempengaruhi minat mahasiswa selain microteaching dan PLP II di Program Studi Pendidikan Akuntansi Unesa adanya efikasi diri. Efikasi diri adalah suatu keadaan seseorang memiliki kepercayaan terhadap kemampuan yang dimilikinya dalam menyusun serta mengerjakan sampai selesai tugas untuk hasil yang diinginkan (Kurniawati \& Rifai, 2018). Efikasi diri orang terbentuk dari tingkat kesulitan dalam menghadapi masalah dalam hidup seseorang. dengan begitu kekuatan dari efikasi diri adalah pengalaman (Septiara \& Listiadi, 2019). Mahasiswa Program Studi Pendidikan Akuntansi yang mempunyai efikasi diri yang tinggi nantinya akan memiliki minat menjadi seorang guru atau pendidik dan juga akan mengerjakan pekerjaan sebagai seorang pendidik dengan sebaik-baiknya sesuai apa yang sudah dipelajarinya di Program Studi Pendidikan Akuntansi Unesa.

Penelitian ini didukung oleh gap research pada variabel PLP II. Penelitian sebelumnya yang diteliti oleh Rahmadiyani dkk (2020) dan Sari dkk (2017) membuktikan bahwa PLP berpengaruh simultan dan parsial kepada variabel minat menjadi guru namun bertentangan pada penelitian yang telah dilaksanakan oleh Pratama dkk (2015) menghasilkan bahwa PLP tidak mempunyai pengaruh secara parsial kepada minat menjadi guru, dikarenakan pengalaman PLP yang rendah sehingga tidak menjadikan PLP berpengaruh kepada minat menjadi guru. 
1185 Pengaruh Pembelajaran Microteaching, Praktik Lapangan Persekolahan, dan Efikasi Diri Terhadap Minat Menjadi Guru SMK Akuntansi - Atika Alifia, Han Tantri Hardini

DOI: https://doi.org/10.31004/edukatif.v4i1.2075

Penelitian terdahulu yang pernah dilaksanakan oleh Tanoyo dkk (2017) menghasilkan bahwa pembelajaran microteaching mempunyai pengaruh pada minat menjadi guru, selain itu Higgins \& Nicholl (2011) menyatakan bahwa microteaching terus di terbarukan untuk mendukung pengajaran kepada mahasiswa guru supaya menjadi guru dan tentunya memiliki minat menjadi guru.

Penelitian sebelumnya yang telah dilaksanakan oleh Febryanti \& Rochmawati (2021) menghasilkan efikasi diri terdapat pengaruh signifikan pada variabel minat menjadi guru secara parsial ataupun simultan, penelitian lain juga mengatakan hal yamg sama yaitu penelitian (Dewi dkk, 2019). Dari penguraian diatas yang diuraikan oleh peneliti maka peneliti memiliki ketertarikan melakukan penelitian "Pengaruh Pembelajaran Microteaching, PLP II, Efikasi Diri terhadap Minat Menjadi Guru Akuntansi” tujuan peneliti mengetahui apakah pembelajaran microteaching, PLP II, dan Efikasi diri memiliki pengaruh signifikan baik secara simultan ataupun parsial terhadap variabel minat menjadi guru pada mahasiswa prodi Pendidikan Akuntansi Fakultas Ekonomika dan Bisnis Unesa.

\section{METODE PENELITIAN}

Menurut pendapat dari Sugiyono (2011) memiliki dua macam atau dua jenis penelitian ialah penelitian kuantitatif dan penelitian kualitatif. Peneliti pada penelitian menggunakan kuantitatif deskriptif. kuantitatif deskriptif yaitu penelitian kuantitatif yang merupakan gambaran fenomena yang terjadi menggunakan statistik (Yusuf, 2014).

Mahasiswa Program studi Pendidikan Akuntansi Fakultas Ekonomika dan Bisnis Universitas Negeri Surabaya yakni sudah atau sedang melaksanakan PLP II dan sudah melaksanakan pembelajaran microteaching adalah mahasiswa angkatan 2018 sehingga sampel yang diambil sejumlah 55 mahasiswa. Dikarenakan sampel kurang dari angka 100 responden atau sampel maka peneliti menggunakan sampel populasi atau seluruh populasi menjadi sampel. Sampel populasi adalah teknik penentuan sampel dengan jumlah populasi relatif sedikit sehingga seluruh bagian populasi merupakan sampel (Sugiyono., 2011).

Kuesioner di dalam penelitian dipakai peneliti untuk teknik pengumpulan data dibuat peneliti memakai skala likert untuk mengukur prilaku individu, gagasan, dan tanggapan terhadap sesuatu yang terjadi di sekitarnya. Penelitian ini memakai skala likert dengan lima kategori respon yaitu: sangat setuju, setuju, cukup setuju, kurang setuju dan sangat tidak setuju. Berikut tabel skor pada skala likert:

Tabel 2

Skor skala likert

\begin{tabular}{ll}
\hline Jawaban & Skor \\
\hline Sangat Setuju & Skor 5 \\
\hline Setuju & Skor 4 \\
\hline Cukup Setuju & Skor 3 \\
\hline Kurang Setuju & Skor 2 \\
\hline Sangat Tidak Setuju & Skor 1 \\
\hline
\end{tabular}

Menurut Nur (2011) terdapat beberapa indikator minat yaitu: (1) memiliki pengetahuan, (2) memiliki keterampilan, (3) memiliki sikap sebagai guru yang profesional. Menurut Mulyasa (2011) variabel PLP memiliki indikator: (1) mempunyai kemampuan pedagogik (2) mempunyai kemampuan kepribadian (3) mempunyai kemampuan sosial (4) mempunyai kemampuan profesional. Variabel Efikasi diri memiliki indikator (1) kemampuan dalam mengelola sebuah kesulitan, (2) kemampuan dalam mengelola keberanian untuk berusaha, (3) Keyakinan diri dalam melaksanakan tugas (Pepe dkk, 2010).

Peneliti menggunakan metode pengumpulan data pada penelitian yaitu kuesioner tertutup atau kuesioner yang sudah ada jawabannya. Responden dalam uji validitas dan reliabilitas berjumlah 33 responden. Peneliti menggunakan metode penelitian regresi linier berganda dan peneliti juga melakukan uji hipotesis sebelumnya melakukan uji prasyarat regresi linier berganda yaitu pengujian asumsi klasik yang mencakup 
1186 Pengaruh Pembelajaran Microteaching, Praktik Lapangan Persekolahan, dan Efikasi Diri Terhadap Minat Menjadi Guru SMK Akuntansi - Atika Alifia, Han Tantri Hardini

DOI: https://doi.org/10.31004/edukatif.v4i1.2075

beberapa uji yaitu uji normalitas, uji multikolinearitas dan uji heteroskedasitas. Untuk melakukan pengujian tersebut peneliti menggunakan program dalam SPSS versi 25.

\section{HASIL DAN PEMBAHASAN PENELITIAN}

Pada variabel penelitian yaitu pembelajaran microteaching, PLP II, efikasi diri memiliki pengaruh untuk minat menjadi guru SMK akuntansi pada mahasiswa prodi pendidikan akuntansi Unesa angkatan 2018. Berikutnya yaitu penjelasan peneliti mengenai tabel deskriptif antara variabel yang didapatkan dari hasil data uji instrument menggunakan skala likert:

\section{Statistik Deskriptif}

Tabel 3

Statistik Deskriptif

\begin{tabular}{lccccc}
\hline \multicolumn{5}{c}{ Descriptive Statistics } \\
\hline & $\mathrm{N}$ & Minimum & Maximum & Mean & Std. Deviation \\
\hline $\begin{array}{l}\text { Pembelajaran } \\
\text { Microteaching }\end{array}$ & 55 & 9 & 45 & 28.11 & 11.460 \\
\hline PLP II & 55 & 12 & 60 & 39.84 & 16.137 \\
\hline Efikasi Diri & 55 & 9 & 45 & 27.51 & 10.737 \\
\hline $\begin{array}{l}\text { Minat Menjadi } \\
\text { Guru }\end{array}$ & 55 & 12 & 60 & 37.75 & 13.581 \\
Valid N (listwise) & 55 & & & & \\
\hline
\end{tabular}

Berdasarkan uji statistika deskriptif dapat dilihat pada variabel dependen minat menjadi guru yang didapatkan dari 55sampel atau responden dengan menggunakan 12 pernyataan atau pertanyaan yang kemudian dilaksanakan analisis maka dapat ditarik kesimpulan data yang benar atau dapat diujikan lebih lanjut dan data hilangnya sejumlah 0 , bernilai rata-rata 37,75, bernilai minimum sebesar 12 dan bernilai maximum sebesar 60, Oleh sebab itu variabel terikat minat menjadi guru SMK akuntansi dapat digolongkan tinggi. Variabel bebas pembelajaran microteaching dengan 55 responden dengan jumlah 9 pertanyaan dan dianalisis maka diperoleh nilai rata-rata 28,11, nilai minimum 9 dan nilai maksimum 45 maka variabel pembelajaran microteaching dapat dikategorikan rendah. Variabel PLP II dengan responden 55 responden dengan jumlah 12 pertanyaan telah dilakukan analisis dengan hasil nilai rata-rata 39,84, nilai minimum 12 dan nilai maksimum 60 dapat disimpulkan variabel PLP II dikategorikan tinggi, yang terakhir variabel efikasi diri dengan 55 responden dan 9 pertanyaan dengan hasil rata-rata 27,51, nilai minimum 9 dan nilai maksimum 60 dapat disimpulkan bahwa efikasi diri dikategorikan rendah.

Tahap selanjutnya adalah melakukan uji prasyarat analisis melalui beberapa uji yaitu uji normalitas, uji multikolinearitas dan uji heteroskedastisitas agar bisa berlanjut dengan dilakukan uji analisis linier berganda.

\section{Uji Normalitas}

Menurut hasil analisis dari uji normalitas yaitu dengan program SPSS Versi 25 dapat dilihat dari tabel p.p plot of regression standardized residual ialah bernilai signifikansi kolmogorof smirnov 0,200 yang artinya $\mathrm{P}>0,05$ dengan begitu data pada penelitian memiliki distribusi dengan normal. Dari data yang memiliki distribusi normal tersebut dapat diartikan bahwa data yang diambil dari kuesioner yang disebarkan peneliti dapat mewakili populasi.

\section{Uji Multikolinearitas}

\section{Tabel 4}

Hasil Uji multikolinearitas

\section{Coefficients $^{\mathbf{a}}$}

Model

$\begin{array}{ccccc}\text { Unstandardized } & \text { Standardized } & & & \text { Collinearity } \\ \text { Coefficients } & \text { Coefficients } & \mathrm{T} & \text { Sig. } & \text { Statistics }\end{array}$


1187 Pengaruh Pembelajaran Microteaching, Praktik Lapangan Persekolahan, dan Efikasi Diri Terhadap Minat Menjadi Guru SMK Akuntansi - Atika Alifia, Han Tantri Hardini

DOI: https://doi.org/10.31004/edukatif.v4i1.2075

\begin{tabular}{llrrrrrr}
\hline & \multicolumn{1}{c}{ B } & \multicolumn{1}{c}{ Std. Error } & \multicolumn{1}{c}{ Beta } & \multicolumn{3}{c}{ Tolerance } & VIF \\
\hline 1 & 11.183 & 3.486 & & 3.208 & .002 & & \\
\hline (Constant) & -.213 & .291 & -.180 & -.733 & .467 & .138 & 7.235 \\
& & & & & & & \\
Pembelajaran & .154 & .184 & .183 & .838 & .406 & .175 & 5.726 \\
Microteaching & .960 & .237 & .759 & 4.048 & .000 & .236 & 4.234 \\
\hline PLP II & Efikasi Diri & & & & & &
\end{tabular}

a. Dependent Variable: Minat Menjadi Guru

Hasil dari uji multikolinearitas pada variabel pembelajaran microteaching, PLP II, dan efikasi diri memiliki VIF < 10 yang berarti bahwa variabel pembelajaran microteaching, PLP II, dan efikasi diri tidak berkorelasi secara sempurna. Serta dari signifikansi variabel bebas memiliki poin lebih tinggi dari 0,05 artinya data tidak terjadi multikolinearitas. Sehingga dapat disimpulkan dari penjabaran diatas bahwa uji multikolinearitas dari seluruh variabel independen tidak memiliki gejala multikolinearitas dalam model regresi.

\section{Uji Hesteroskedasitas}

Scatterplot

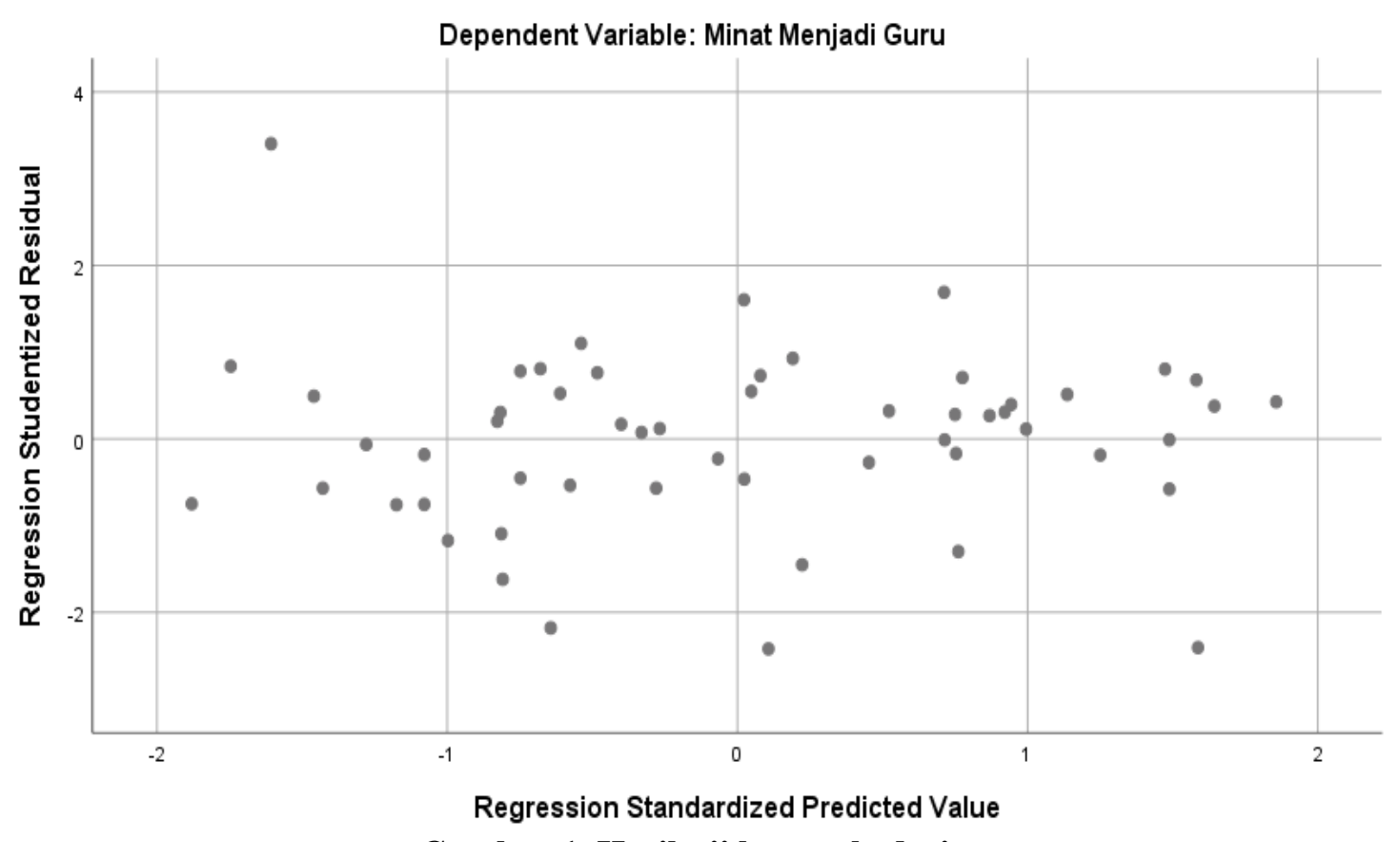

Gambar 1. Hasil uji hesterokedasitas

Hasil uji hesteroskedasitas diperoleh hasil pada tabel diatas dengan nilai signifikan variabel independen $>0,05$. Selain itu hasil dengan melihat grafik scatterpot dapat diperoleh hasil data yang penyebarannya secara acak dan tidak berbentuk pola tertentu oleh sebab itu dapat peneliti menyimpulkan bahwa tidak memiliki gejala hesteroskedasitas dalam model regresi penelitian ini.

Selanjutnya setelah melakukan uji prasyarat analisis selanjutnya peneliti melakukan analisis regresi linier berganda dengan hasil yaitu: 
1188 Pengaruh Pembelajaran Microteaching, Praktik Lapangan Persekolahan, dan Efikasi Diri Terhadap Minat Menjadi Guru SMK Akuntansi - Atika Alifia, Han Tantri Hardini

DOI: https://doi.org/10.31004/edukatif.v4i1.2075

\section{Hasil Analisis Regresi Linier Berganda}

Tabel 5

Hasil Analisis Regresi Linier Berganda

\begin{tabular}{|c|c|c|c|c|c|c|c|c|c|c|c|}
\hline \multicolumn{12}{|c|}{ Coefficients $^{\mathrm{a}}$} \\
\hline & \multirow{2}{*}{ Model } & \multicolumn{2}{|c|}{$\begin{array}{c}\text { Unstandardized } \\
\text { Coefficients }\end{array}$} & \multirow{2}{*}{$\begin{array}{c}\text { Standardized } \\
\text { Coefficients } \\
\text { Beta }\end{array}$} & \multirow[b]{2}{*}{ l } & \multirow{2}{*}{ Sig. } & \multicolumn{3}{|c|}{ Correlations } & \multicolumn{2}{|c|}{$\begin{array}{l}\text { Collinearity } \\
\text { Statistics }\end{array}$} \\
\hline & & B & Std. Error & & & & $\begin{array}{l}\text { Zero- } \\
\text { order }\end{array}$ & Partial & Part & $\begin{array}{c}\text { Toleran } \\
\text { ce }\end{array}$ & VIF \\
\hline \multirow{4}{*}{1} & (Constant) & 11.183 & 3.486 & & 3.208 & .002 & & & & & \\
\hline & $\begin{array}{l}\text { Pembelajaran } \\
\text { Microteaching }\end{array}$ & -.213 & .291 & -.180 & -.733 & .467 & .644 & -.102 & -.067 & .138 & 7.235 \\
\hline & PLP II & .154 & .184 & .183 & .838 & .406 & .650 & .117 & .076 & .175 & 5.726 \\
\hline & Efikasi Diri & .960 & .237 & .759 & 4.048 & .000 & .755 & .493 & .369 & .236 & 4.234 \\
\hline
\end{tabular}

Dilihat dari tabel didapatkan hasil yaitu:

$\mathrm{Y}=11,183-0,213 \mathrm{X} 1+0,154 \mathrm{X} 2+0,960 \mathrm{X}$

Berdasarkan hasil diatas memiliki arti bahwa: (1) Memiliki besar Constant sebesar 11,183 mempunyai arti ketika pembelajaran microteaching (X1), PLP II (X2) dan Efikasi Diri (X3) nilainnya 0, Maka variabel dependen minat menjadi guru (Y) bernilai 11,183. (2) Memiliki besar cofficients (B) pada pembelajaran microteaching (X1) dengan besar -0,213; artinya jika variabel pembelajaran microteaching terjadi kenaikan satu satuan, selain itu variabel PLP II (X2) dan variabel efikasi diri (X3) nilainya tidak berubah, Jadi akan terjadi senilai $-0,231$ penurunan nilai pada variabel dependen minat menjadi guru (Y) akan tetapi variabel lainnya memiliki nilai konstan. (3) Cofficients dari variabel independen PLP II (X2) dengan besar 0,154; artinya jika variabel PLP II (X2) terjadi kenaikan satu satuan, Selain itu variabel pembelajaran microteaching (X1) dan Efikasi Diri (X3) memiliki nilai tidak berubah, Sehingga variabel dependen minat menjadi guru (Y) terjadi peningkatan sebesar 0,154. Cofficients regresi linier berganda dari variabel efikasi diri (X3) senilai 0,960; artinya jika variabel efikasi diri (X3) terjadi peningkatan satu satuan, Sementara itu variabel pembelajaran microteaching (X1) dan PLP II (X2) nilai tidak berubah, dapat disimpulkan variabel dependen minat menjadi guru (Y) bakal terjadi suatu kenaikan sebesar 0,960.

\section{Hasil Uji F (Pengujian Secara Simultan)}

Tabel 6

Hasil Uji F (Pengujian Secara Simultan)

\begin{tabular}{|c|c|c|c|c|c|c|}
\hline \multicolumn{7}{|c|}{ ANOVA $^{a}$} \\
\hline Model & & Sum of Squares & Df & Mean Square & $\mathrm{F}$ & Sig. \\
\hline \multirow[t]{3}{*}{1} & Regression & 5739.908 & 3 & 1913.303 & 23.120 & $.000^{\mathrm{b}}$ \\
\hline & Residual & 4220.529 & 52 & 82.755 & & \\
\hline & Total & 9960.436 & 55 & & & \\
\hline
\end{tabular}

$\mathrm{F}_{\text {tabel }}$ didiperoleh dengan cara perhitungan dibawah ini :

$$
\begin{aligned}
\mathrm{F}_{\text {tabel }} & =\mathrm{F}(3 ; 55-3) \\
& =\mathrm{F}(3 ; 55-3) \\
& =\mathrm{F}(3 ; 52) \\
& =2,400
\end{aligned}
$$

Dilihat dari tabel diatas menunjukan hasil bahwa besarnnya $F_{\text {hitung }}$ dengan nilai sebesar 23,120 maka nilai lebih tinggi dari $F_{\text {tabel }}$ yaitu sejumlah 2,400 sedangkan jumlah signifikansi 0,000 nilainnya lebih rendah 
1189 Pengaruh Pembelajaran Microteaching, Praktik Lapangan Persekolahan, dan Efikasi Diri Terhadap Minat Menjadi Guru SMK Akuntansi - Atika Alifia, Han Tantri Hardini

DOI: https://doi.org/10.31004/edukatif.v4i1.2075

dari nilai 0,05 , jadi bisa dikatakan variabel independen pembelajaran microteaching, PLP II dan efikasi diri dengan cara simultan terdapat pengaruh signifikan pada variabel terikat minat menjadi guru.

\section{Hasil Uji t (Pengujian Secara Parsial)}

Tabel 7

Hasil Uji t (Pengujian Secara Parsial) Coefficients $^{\mathbf{a}}$

\begin{tabular}{|c|c|c|c|c|c|c|}
\hline \multicolumn{7}{|c|}{ Coefficients $^{\mathrm{a}}$} \\
\hline \multirow[b]{2}{*}{ Model } & & \multicolumn{2}{|c|}{ Unstandardized Coefficients } & $\begin{array}{l}\text { Standardized } \\
\text { Coefficients }\end{array}$ & \multirow[b]{2}{*}{$\mathrm{T}$} & \multirow[b]{2}{*}{ Sig. } \\
\hline & & $\mathrm{B}$ & Std. Error & Beta & & \\
\hline 1 & (Constant) & 11.183 & 3.486 & & 3.208 & .002 \\
\hline & Pembelajaran Microteaching & -.213 & .291 & -.180 & -.733 & .467 \\
\hline & PLP II & .154 & .184 & .183 & .838 & .406 \\
\hline & Efikasi Diri & .960 & .237 & .759 & 4.048 & .000 \\
\hline
\end{tabular}

Berdasarkan tabel uji t diatas dapat dilihat menghasilkan uji t (uji secara parsial) pada variabel pembelajaran microteaching, PLP II, efikasi diri: (1) Variabel pembelajaran microteaching tidak mempunyai pengaruh signifikan kepada variabel minat menjadi guru dapat dilihat besarnya $t_{\text {hitung }}$ bernilai $0,733<t_{\text {tabel }}$ bernilai 1,674, dan mempunyai sig. sebesar 0,467>0,05. (2) Variabel PLP II (X2) dinyatakan tidak mempunyai pengaruh signifikan pada variabel dependen minat menjadi guru, didapatkan dari besar $\mathrm{t}_{\text {hitung }}$ bernilai $0,838<\mathrm{t}_{\text {tabel }}$ bernilai 1,674 , dimana jumlah nilai sig. sebesar0,406 $>0,05$.(3) Variabel efikasi dari berpengaruh positif dan tidak signifikan. Dibuktikan dengan $t_{\text {hitung }}$ senilai $0,838<1,674$, dimana jumlah nilai sig. 0,406>0,05.(4)Variabel efikasi diri berpengaruh signifikan. Dibuktikan dengan $t_{\text {hitung }}$ senilai 4,048 $>t_{\text {tabel }}$ 1,674 , dimana jumlah sig. $0,000<0,05$.

Bersama dengan itu nilai dari standardized coefficients beta menyediakan hasil seberapa besarnya variabel bebas mempunyai pengaruh pada variabel terikat. Variabel besarnya berpengaruh terhadap minat menjadi guru yakni variabel Pembelajaran Microteaching nilainya 0,180, PLP II nilainya 0,183, Efikasi Diri sebesar 0,759 .

\section{Hasil Uji R2 (Koefisien Determinasi)}

\section{Tabel 8}

Hasil Uji R2

\begin{tabular}{llrcc}
\hline \multicolumn{4}{c}{ Model Summary $^{\mathbf{b}}$} \\
\hline Model & $\mathrm{R}$ & R Square & Adjusted R Square & Std. Error of the Estimate \\
1 & $.759^{\mathrm{a}}$ & .576 & .551 & 9.097 \\
\hline
\end{tabular}

Menurut tabel diatas didapatkan dari $\mathrm{R}$ square dengan jumlah 0,551 dapat peneliti artikan dari variabel pembelajaran microteaching, PLP II, efikasi diri mempunyai pengaruh pada variabel minat menjadi guru senilai $57,6 \%$ sementara $42,4 \%$ pengaruh minat menjadi guru dikarenakan variabel bebas yang tidak digunakan pada penelitian atau variabel lain selain variabel independen pada penelitian.

\section{Pengaruh Pembelajaran Microteaching, PLP II, Efikasi Diri untuk Minat Menjadi Guru}

Setelah peneliti melakukan uji $\mathrm{F}$ dapat diperoleh hasil $\mathrm{F}_{\text {hitung }}$ dengan besar 23,120 $>\mathrm{F}_{\text {tabel }}$ dengan besar 2,400 dimana bernilai signifikan 0,000 $<0,05$. Dengan begitu disimpulkan memiliki pengaruh secara simultan antara pembelajaran microteaching, PLP II, efikasi diri untuk minat menjadi guru. koefisien determinasi (R2) terletak pada Adjusted R Square didapatkan nilai 0,551 artinya pembelajaran microteaching, PLP II, efikasi diri memiliki kontribusi senilai 57,6\% sisanya didapatkan pada variabel bebas lain yang berbeda dari variabel independen dalam penelitian, contohnya dorongan teman sebaya, persepsi mengenai guru, dukungan keluarga dan lain-lain.

Koefisian determinasi (R2) juga mempunyai artian seluruh variabel independen yaitu pembelajaran microteaching, PLP II, efikasi diri memberikan kontribusi kepada mahasiswa agar memiliki minat menjadi 
1190 Pengaruh Pembelajaran Microteaching, Praktik Lapangan Persekolahan, dan Efikasi Diri Terhadap Minat Menjadi Guru SMK Akuntansi - Atika Alifia, Han Tantri Hardini

DOI: https://doi.org/10.31004/edukatif.v4i1.2075

guru akuntansi. Hal tersebut dikarenakan tingginya keyakinan diri mahasiswa atas kesanggupan mahasiswa jadi guru yang profesional, Kepercayaan mahasiswa mampu menjadi guru juga didapatkan dari pembelajaran yang berkaitan dengan keguruan seperti pembelajaran microteaching. selain itu juga terdapat pembelajaran melalui praktik langsung ke sekolahan yaitu PLP II untuk meningkatkan skill keguruan yang dimiliki mahasiswa.

\section{Tidak Terdapat Pengaruh Pembelajaran Microteaching Untuk Minat Menjadi Guru}

Uji $t$ yang telah dilakukan dihasilkan $t_{\text {hitung }}$ dengan jumlah $0,733<t_{\text {tabel }} 1,674$ dan sig. sebesar 0,467>0,05. Oleh sebab itu, Bisa diartikan pembelajaran microteaching tidak berpengaruh dan tidak signifikan untuk variabel minat menjadi guru.

Pembelajaran microteaching merupakan pembelajaran yang wajib di pelajari pada jurusan keguruan (Asril, 2018). Menurut Helmiati (2013) microteaching adalah suatu pembelajaran atau penugasan untuk melatih keterampilan mengajar. Dari dua penjelasan diatas dapat di simpulkan bahwa microteaching merupakan proses pembelajaran yang wajib dilakukan oleh mahasiswa jurusan pendidikan dan berguna untuk melatih keterampilan mengajar mahasiswa seharusnya mahasiswa memiliki minat menjadi guru yang tinggi saat melaksanakan pembelajaran microteaching akan tetapi ternyata hasil dari uji $\mathrm{T}$ pembelajaran microteaching untuk minat menjadi guru tidak berpengaruh tentunya terdapat faktor penyebab tidak berpengaruh di dalamnya.

Faktor penyebab tidak ber pengaruhnya pembelajaran microteaching untuk minat menjadi guru didapatkan peneliti dari hasil wawancara kepada sampel dan didapatkan hasil penyebab pembelajaran microteaching tidak berpengaruh untuk minat menjadi guru dikarenakan pembelajaran microteaching yang dilakukan secara daring, pembelajaran microteaching dilakukan saat pelaksanaan KKN, dan pembelajaran microteaching dilakukan di rumah dengan media seadanya sehingga dapat disimpulkan bahwa pembelajaran microteaching yang dilakukan mahasiswa S1pendidikan akuntansi tidak dilakukan secara maksimal sehingga menyebabkan tidak ber pengaruhnya pembelajaran microteaching untuk minat menjadi guru.

\section{Tidak Terdapat Pengaruh PLP II Untuk Minat Menjadi Guru}

Uji t didapatkan jumlah $t_{\text {hitung }}$ dengan besar $0,838<t_{\text {tabel }}$ dengan nilai 1,674 dan juga nilai signifikan 0,406>0,05. Dengan begitu diartikan PLP II tidak berpengaruh dan tidak signifikan untuk minat menjadi guru. Setelah melakukan uji $\mathrm{t}$ dengan hasil sebanyak 0,838 dengan begitu dapat disimpulan bahwa tidak memiliki pengaruh positif.

PLP II merupakan suatu tahapan atau proses yang dilakukan untuk menyiapkan guru-guru profesional pada program sarjana pendidikan, berupa suatu tugas untuk mengimplementasikan hasil belajar mahasiswa kepada satuan pendidikan (Universitas Negeri Surabaya, 2021). Dari penjelasan diatas dapat peneliti simpulkan bahwa PLP II adalah kegiatan yang dilakukan mahasiswa jurusan pendidikan untuk mengimplementasikan hasil belajar mahasiswa kepada satuan pendidikan. Seharusnya PLP II untuk minat menjadi guru akan tetapi dari uji t yang dilakukan menunjukan bahwa PLP II tidak berpengaruh untuk minat menjadi guru.

Hasil uji t sependapat dengan Pratama dkk (2015) yang mengatakan bahwa PLP tidak memiliki pengaruh terhadap minat menjadi guru. Peneliti juga melakukan wawancara kepada sampel terkait penyebab tidak ber pengaruhnya PLP II untuk minat menjadi guru yaitu dikarenakan sampel melakukan PLP II lebih banyak dengan daring dan minat siswa sangat kecil dalam pembelajaran sehingga membuat tidak ber pengaruhnya PLP II untuk minat menjadi guru.

\section{Terdapat Pengaruh Efikasi Diri Untuk Minat Menjadi Guru}

Dari uji $\mathrm{t}_{\mathrm{hitung}}$ berjumlah 4,048 $<\mathrm{t}_{\text {tabel }}$ berjumlah 1,674 signifikan sebesar $0,000<0,05$. Dapat dijelaskan Efikasi Diri memiliki pengaruh dengan positif signifikan untuk minat menjadi guru. Setelah melakukan uji t yang menunjukan 4,048 lalu dapat disimpulan bahwa memiliki pengaruh positif. 
1191 Pengaruh Pembelajaran Microteaching, Praktik Lapangan Persekolahan, dan Efikasi Diri Terhadap Minat Menjadi Guru SMK Akuntansi - Atika Alifia, Han Tantri Hardini

DOI: https://doi.org/10.31004/edukatif.v4i1.2075

Efikasi Diri ialah kepercayaan seseorang dalam keahlian untuk mengerjakan suatu pekerjaan (Maftuhah \& Suratman, 2015). Efikasi diri seseorang terbentuk dari tingkat kesulitan dalam menghadapi masalah dalam hidup seseorang dengan begitu kekuatan dari efikasi diri adalah pengalaman (Septiara \& Listiadi, 2019). Dari kedua penjabaran peneliti menyimpulkan efikasi diri yaitu rasa percaya seseorang pada dirinya untuk mampu mengerjakan sampai selesai suatu tugas yang ada dan kepercayaan diri tersebut terbentuk karena terdapatnya pengalaman dalam hidup seseorang tersebut. Maka dapat dikatakan orang yang punya efikasi diri yang tinggi sama dengan punya pengaruh untuk minat menjadi guru.

Hasil Uji t sependapat dengan Rahmadiyani dkk (2020) efikasi diri terdapat pengaruh pada minat menjadi guru. Sependapat juga dengan Aini (2018) efikasi diri mempunyai pengaruh pada minat menjadi guru ekonomi.

\section{KESIMPULAN}

Berdasarkan penelitian yang berjudul Pengaruh Pembelajaran Microteaching, PLP II, dan Efikasi Diri untuk Minat Menjadi Guru Akuntansi didapatkan kesimpulan secara simultan terdapat pengaruh positif serta signifikan Pembelajaran Microteaching, PLP II, Efikasi Diri pada Minat Menjadi Guru Akuntansi akan tetapi Uji t statistic mengatakan bahwa variabel Pembelajaran Microteaching tidak berpengaruh dan tidak signifikan untuk minat menjadi guru begitu juga variabel PLP II tidak berpengaruh dan tidak signifikan pada minat menjadi guru, Sedangkan Efikasi Diri terdapat pengaruh dan signifikan untuk minat menjadi guru.

Berdasarkan pada pemaparan, peneliti menyarankan yaitu:

1. Penelitian akan menambah pengetahuan atau wawasan bagi pembaca terkait pengaruh pembelajaran microteaching, PLP II, dan efikasi diri pada minat menjadi guru akuntansi.

2. Saran untuk peneliti lain yaitu penelitian dapat dilakukan kepada alumni atau bahkan bisa dilakukan di Universitas lain.

\section{DAFTAR PUSTAKA}

Aini, E. N. (2018). Pengaruh Efikasi Diri dan Persepsi terhadap Minat Menjadi Guru Ekonomi Pada Mahasiswa Program Studi Pendidikan Ekonomi 2015 UNESA. JPEKA: Jurnal Pendidikan Ekonomi, Manajemen Dan Keuangan, 2(2), 83. https://doi.org/10.26740/jpeka.v2n2.p83-96

Asril, Z. (2018). Microteaching. Rajawali Pers.

Dewi, dkk. (2019). Hubungan Antara Persepsi Tentang Profesi Guru dan Efikasi Diri (Self Efficacy) Dengan Minat Menjadi Guru Akuntansi Pada Mahasiswa Program Studi Pendidikan Akuntansi Universitas Sebelas Maret. Jurnal "Tata Arta” UNS, 5(3), 35-51. https://jurnal.uns.ac.id/tata/article/view/39893

Febryanti, \& Rochmawati. (2021). Sejarah Artikel: Diterima April 2021, Disetujui Mei 2021, Dipublikasikan Juni 2021. 9, 43-56.

Helmiati. (2013). Microteaching Melatih Keterampilan Dasar Mengajar. Aswaja Pressindo.

Higgins, A., \& Nicholl, H. (2011). The experiences of lecturers and students in the use of microteaching as a teaching strategy. In Nurse Education in Practice (Vol. 3, Issue 4). https://doi.org/10.1016/S14715953(02)00106-3

Karyantini, D. A., \& Rochmawati. (2021). Pengaruh Hasil Belajar Micro Teaching dan Lingkungan Keluarga Terhadap Minat Menjadi Guru Akuntansi Melalui Efikasi Diri Sebagai Variabel Moderasi. Jurnal Pendidikan Akuntansi (JPAK), 9(2), 52-61.

KBBI. (2021). No Title. KBBI.

Kurniawati, Y. I., \& Rifai, M. E. (2018). Pentingnnya Layanan Informasi Karier dan Efikasi Diri dalam Pengambilan Keputusan Studi Lanjut Siswa. CV. Sindunata.

Maftuhah, R., \& Suratman. (2015). Pengaruh Efikasi Diri, Lingkungan Keluarga, dan Pengetahuan 
1192 Pengaruh Pembelajaran Microteaching, Praktik Lapangan Persekolahan, dan Efikasi Diri Terhadap Minat Menjadi Guru SMK Akuntansi - Atika Alifia, Han Tantri Hardini

DOI: https://doi.org/10.31004/edukatif.v4i1.2075

Kewirausahaan Terhadap Minat Berwirausaha Siswa SMK di Sidoarjo. 3.

Mulyasa, E. (2011). Menjadi Guru Profesional.

Nugroho, dkk. (2016). Analisis Faktor-Faktor Yang Mempengaruhi Minat Menjadi Guru Pada Mahasiswa Prodi Pendidikan Ekonomi. Jurnal Pendidikan Dan Pembelajaran Khatulistiwa, 5(10), 1-11.

Nur, H. (2011). Keterampilan Dasar Dalam Proses Belajar/Micro Teaching. Unismuh Makassar Press.

Pepe, dkk. (2010). Work Self-Efficacy Scale and Search for Work Self-Efficacy Scale : A Validation Study in Spanish and Italian Cultural Contexts Escala de Autoeficacia en el Trabajo y Escala de Autoeficacia para la Búsqueda de Empleo : Estudio de Validez en Contextos Cultu.

Pratama, dkk. (2015). Pengaruh Prestasi PPL, Penguasaan Kompetensi Profesional, dan Motivasi Mahasiswa Terhadap Kesiapan Menjadi Guru Mata Pelajaran Ekonomi/Akuntansi yang Profesional. Jurnal Penelitian Pendidikan, 32(1), 11-17.

Rahmadiyani, S., Hariani, L. S., \& Yudiono, U. (2020). Minat Menjadi Guru: Persepsi Profesi Guru, Pengenalan Lapangan Persekolahan (PLP) dan Efikasi Diri. Jurnal Riset Pendidikan Ekonomi, 5(1) https://doi.org/10.21067/jrpe.v5i1.4304

Sari, dkk. 2017). Pengaruh Pembelajaran Micro Teaching dan Program Pengalaman Lapangan (PPL) Terhadap Minat Menjadi Guru Pada Mahasiswa. Jurnal Universitas Negeri Surakarta, 3(2), 1-14.

Septiara, V. I., \& Listiadi, A. (2019). Pengaruh Persepsi Profesi Guru, Efikasi Diri, dan Program Pengelolaan Pembelajaran (PPP) terhadap Minat Menjadi Guru Akuntansi Mahasiswa Prodi Pendidikan Akuntansi 2015 Fakultas Ekonomi UNESA. Jurnal Pendidikan Akuntansi, 7(3), 315-318.

https://jurnalmahasiswa.unesa.ac.id/index.php/jpak/article/view/30512/27807

Sugiyono. (2011). Metode Penelitian Pendidikan Pendekatan Kuantitatif, Kualitatif, dan R \& D. Alfabeta.

Tanoyo, dkk. (2017). Pengaruh Lingkungan Keluarga, Pengalaman Belajar Micro Teaching Dan Prestise Profesi Guru Terhadap Motivasi Menjadi Guru. Jurnal Riset Pendidikan Ekonomi, 2(2), 1-8. http://ejournal.unikama.ac.id

Undang-Undang tentang Guru dan dosen, Pub. L. No. 14, 25 (2005).

Universitas Negeri Surabaya, S. M. B. kampus. (2021). Buku Pedoman Divisi Praktik Kegiatan Lapangan Satuan Merdeka Belajar Kampus Merdeka Universitas Negeri Surabaya. Universitas Negeri Surabaya.

Yuniasari, T., \& Djazari, M. (2017). Pengaruh Minat Menjadi Guru, Lingkungan Keluarga, dan Praktik Pengalaman Lapangan (PPL) Terhadap Kesiapan Menjadi Guru Akuntansi Mahasiswa Pendidikan Akuntansi Angkatan 2013 Fe Uny. Jurnal Basicedu, 15(2), 707-715.

https://doi.org/10.31004/basicedu.v4i3.424

Yusuf, A. M. (2014). Metode Penelitian Kuantitatif, Kualitatif \& Penelitian Gabungan. PT Fajar Interpratama Mandiri. 